\title{
Development of Rice Bran Mixed Porous Clay Bricks for Permeable Pavements: A Sustainable LID Technique for Arid Regions
}

\author{
Fawaz Alharbi ${ }^{1}$, Meshal Almoshaogeh ${ }^{1} \mathbb{D}$, Md. Shafiquzzaman ${ }^{1, *} \mathbb{D}$, Husnain Haider ${ }^{1} \mathbb{D}$, Md. Rafiquzzaman ${ }^{2}$, \\ Ahmed Alragi ${ }^{1}$, Sherif ElKholy ${ }^{1}$, ELSaid Abdallah Bayoumi ${ }^{1}$ and Yassine EL-Ghoul ${ }^{3}$ \\ 1 Department of Civil Engineering, College of Engineering, Qassim University, Buraidah 52571, Saudi Arabia; \\ f.a@qec.edu.sa (F.A.); m.moshaogeh@qec.edu.sa (M.A.); husnain@qec.edu.sa (H.H.); \\ afelragi@qec.edu.sa (A.A.); selkholy@qec.edu.sa (S.E.); eng_said60@qec.edu.sa (E.A.B.) \\ 2 Department of Industrial Engineering and Management, Khulna University of Engineering and Technology, \\ Khulna 9203, Bangladesh; rafiq123@iem.kuet.ac.bd \\ 3 Department of Chemistry, College of Science, Qassim University, Buraidah 52571, Saudi Arabia; \\ y.elghoul@qu.edu.sa \\ * Correspondence: shafiq@qec.edu.sa
}

\section{check for} updates

Citation: Alharbi, F.; Almoshaogeh, M.; Shafiquzzaman, M..; Haider, H.; Rafiquzzaman, M..; Alragi, A.; ElKholy, S.; Bayoumi, E.A.; EL-Ghoul, Y. Development of Rice Bran Mixed Porous Clay Bricks for Permeable Pavements: A Sustainable LID Technique for Arid Regions. Sustainability 2021, 13, 1443. https://doi.org/10.3390/ su13031443

Academic Editor: Luisa Molari

Received: 22 December 2020

Accepted: 25 January 2021

Published: 29 January 2021

Publisher's Note: MDPI stays neutral with regard to jurisdictional claims in published maps and institutional affiliations.

Copyright: (c) 2021 by the authors. Licensee MDPI, Basel, Switzerland. This article is an open access article distributed under the terms and conditions of the Creative Commons Attribution (CC BY) license (https:// creativecommons.org/licenses/by/ $4.0 /)$.

\begin{abstract}
Permeable pavement provides sustainable solutions for urban stormwater management. In this research, the potential of rice bran mixed porous clay bricks were evaluated for permeable pavements. Physical, mechanical and hydrological properties along with stormwater treatment capabilities of the brick samples were assessed. The study found that ratio of rice bran and clay soil has significant impacts on the properties of the produced bricks. Water adsorption and porosity increased with increasing rice bran ratio. Compressive strength of brick samples decreased from 29.6 $\mathrm{MPa}$ to $6.9 \mathrm{MPa}$ when the ratio of rice bran was increased from $0 \%$ to $20 \%$. The permeability coefficient increased from $4 \times 10^{-4}$ to $1.39 \times 10^{-2} \mathrm{~mm} / \mathrm{s}$ with the increase in rice bran from $0 \%$ to $30 \%$. The preamble clay bricks were efficient to remove turbidity, total suspended solids (TSS), five days' biochemical oxygen demand (BOD5), and heavy metals ( $\mathrm{Mn}, \mathrm{Cu}$, and $\mathrm{Zn}$ ) from stormwater to meet the World Health Organization (WHO) standard for wastewater reuse application. The bricks with $\leq 10 \%$ of rice bran achieved the American Society for Testing and Materials (ASTM) standard of the desire compressive strength and permeability coefficient for pedestrian and light traffic pavements. The porous bricks prepared in this study can be used to construct permeable pavements and would be a sustainable low impact developments technique for stormwater management in urban areas.
\end{abstract}

Keywords: permeable clay bricks; permeable pavement; rice bran; clay soil; compressive strength; coefficient of permeability; contaminant removal

\section{Introduction}

Arid regions, such as Saudi Arabia, are facing multiple challenges due to climate change, such as rising temperatures, varying rainfall patterns, and high evaporation losses [1,2]. In addition, rapid development activities are drastically increasing impervious surfaces in urban areas [3]. This increase in the impervious area reduces infiltration and increases surface runoff and subsequent pollution loads to receiving water bodies $[4,5]$. In arid and semi-arid regions, drainage infrastructure was constructed for low intensity and short return period floods. Global climate change in the recent past has enhanced flash floods' frequencies that resulted in significant socio-economic and environmental losses in these regions [6]. Since the recent past, sustainable water sensitive urban design (WSUD) and low-impact development (LID) approaches have been replacing conventional stormwater drainage schemes to address these issues [7]. These terms have been used interchangeably around the World. For instance, WSUD originated from Australia in the 1990s, while LID is a more commonly used terminology in North America and New 
Zealand [8]. The present research adopts the term LID to evaluate the effectiveness of permeable pavements manufactured using natural materials.

In the recent past, permeable (or pervious) pavements received plenty of attention with regard to stormwater management because of their unique infiltration properties [9]. A permeable pavement consists of a multilayered structure, mostly with permeable subbase and base layers, permeable bedding-layer (if required), and top permeable-surface. Thicknesses of these layers depend on the traffic (or penetration) loading conditions [10]. The permeable pavement works as a reservoir for runoff storage and consequently reduces peak flows to the drainage infrastructure through filtration [11-14]. Simultaneously, the permeable pavement acts as a filter and has an incredible filtration capacity to remove various pollutants from stormwater runoff, e.g., total suspended solids (TSS), organic matter, turbidity, nutrients (e.g., nitrogen and phosphorus), heavy metals (e.g., $\mathrm{Cu}, \mathrm{Pb}$, and $\mathrm{Zn}$ ), and hydrocarbons $[15,16]$. Pagotto et al. [17] compared the performance of conventional pavement with permeable pavement in Nantes, France, and reported $74 \%$ reduction in heavy metals, $87 \%$ retention of solids, and $90 \%$ interception of hydrocarbons.

Past studies evaluated permeable asphalt-based and concrete-based pavements consisting of different porous layers; these layers improve runoff infiltration to the underlying drainage system $[18,19]$. Granulometry material with a small quantity of fines comprise the base-and-sub-base layers to attain a large void ratio [20]. Marcaida et al. [21] found that the sizes of both the aggregates and clogging particles play a role in particle-related clogging of porous concrete pavements (PCP). Elizondo-Martinez et al. [22] evaluated the impact of alternative materials to replace cement in PCP and found that replacing a small percentage of cement with metakaolin increased both the infiltration and structural characteristics. They also reported that without adjusting the mix design, geopolymer mixtures improve the permeability but indirectly decrease the tensile strength of PCP. Recently, Sprouse III et al. [23] examined three continuing problems in PCP applications, including conflicting nomenclature, flawed testing standards, and the absence of an inclusive design framework.

Energy consumed in material production and other construction and maintenance activities results in high environmental impacts (e.g., human toxicity, fossil fuel consumption, and global warming) over the conventional pavement life cycle [24]. This decade, several studies have conducted life cycle assessment (LCA) of PCP [10]. Wang et al. [25] conducted LCA for both asphalt-based and concrete-based permeable pavements. They reported $49 \mathrm{TJ}$ of energy, 6700 tons of $\mathrm{CO}_{2}$ emissions, and 0.1 and 1.0 tons of lead and zinc emission reduction by replacing the conventional with porous pavements. Spatari et al. [26] evaluated the impact of LID, i.e., replacing conventional pavement with permeable pavement in an urban sidewalk, on the reduction of greenhouse gas emissions. They reported $7.3 \mathrm{GJ}$ energy and 0.4 tons of greenhouse emissions reduction with the implementation of their strategy on an urban neighborhood in New York. Li et al. [27] compared different sustainable drainage systems (permeable pavements, green roofs, and wetlands) based on their environmental impacts over the life cycle, from construction to disposal. They found that conventional permeable pavements showed the highest abiotic depletion potential amongst all the options, primarily due to the higher use of building materials in their manufacturing.

Organic construction materials are more eco-friendly alternatives with less adverse impacts on the natural environment and human health [28]. A permeable clay brick pavement can be an effective urban stormwater management option. With low cost and simple manufacturing technology, permeable clay brick pavements can help in achieving the LID's goals in arid regions. Previous studies mixed various eco-friendly waste materials with clay soil to produce porous bricks to achieve sustainability and minimize environmental impacts. The use of certain amounts of waste material (5-30\%) is an innovative way to generate pore in clay bricks. Until now several waste materials, including fly-ash, rice husk, rice straw, sugarcane base waste, and other waste from agricultural and industrial sources have been effectively applied in the production of lightweight clay-based bricks [29-33]. The application of those porous clay bricks made with different pore-forming agents is lim- 
ited as building materials for constructing walls and floors. For permeable pavers, porous clay bricks can replace the permeable interlocking in concrete pavements. The porous clay bricks are appropriate for any public or private setting where impervious cover is to be limited and traffic load is pedestrian or light vehicular (e.g., bicycle) [34].

A review of literature revealed that past studies extensively investigated conventional concrete-based permeable pavements, while permeable clay-based pavements constructed with natural materials have yet to be examined for their sustainable applications. As per the authors' best knowledge, structural, hydrological, and storm water treatment performances of porous clay bricks have not been adequately studied to date. The present study aimed to develop a clay-based pervious brick for light traffic participants, such as pedestrians and cycling in urban areas of arid regions. The study also assessed structural (i.e., physical and mechanical properties, including porosity, water adsorption, bulk density, compressive strength, and flexural strength), hydrological (permeability), and stormwater treatment (through filtration) performances of the bricks manufactured with different ratios of clay soil and rice bran.

\section{Material and Methods}

\subsection{Material}

The clay soil for brick manufacturing was collected from a local brick field at Khulna Division located in South-Western Region of Bangladesh. The soil was collected from bulk storage, where the soil was stored for manufacturing clay bricks for building and road construction. Subsequently, manual screening of the soil sample was performed to remove straw, shells, and other impurities. The final sample was prepared by oven drying at $110{ }^{\circ} \mathrm{C}$ for $24 \mathrm{~h}$, grounding with a hammer, and passing through a $0.5-\mathrm{mm}$ sieve. The particle size distribution of the final soil was measured by the laser diffraction method (Shimadzu SALD 3000, Kyoto, Japan). The distribution showed that soil contained approximately $10.8 \%$ coarse sand, $75.5 \%$ fine sand, $11.6 \%$ silt, and $2.1 \%$ clay. The soil properties presented in Figure 1 and Table 1 are appropriate to manufacture clay bricks for building and road construction [35].

Rice bran (RB) was collected from a local rice mill operating in the Khulna City, Southwestern Region of Bangladesh. After collection, the RB was washed with tap water and dried in an oven at $110^{\circ} \mathrm{C}$ for $24 \mathrm{~h}$. The dried RB was finally passed through a $1 \mathrm{~mm}$ sieve for manufacturing porous bricks.

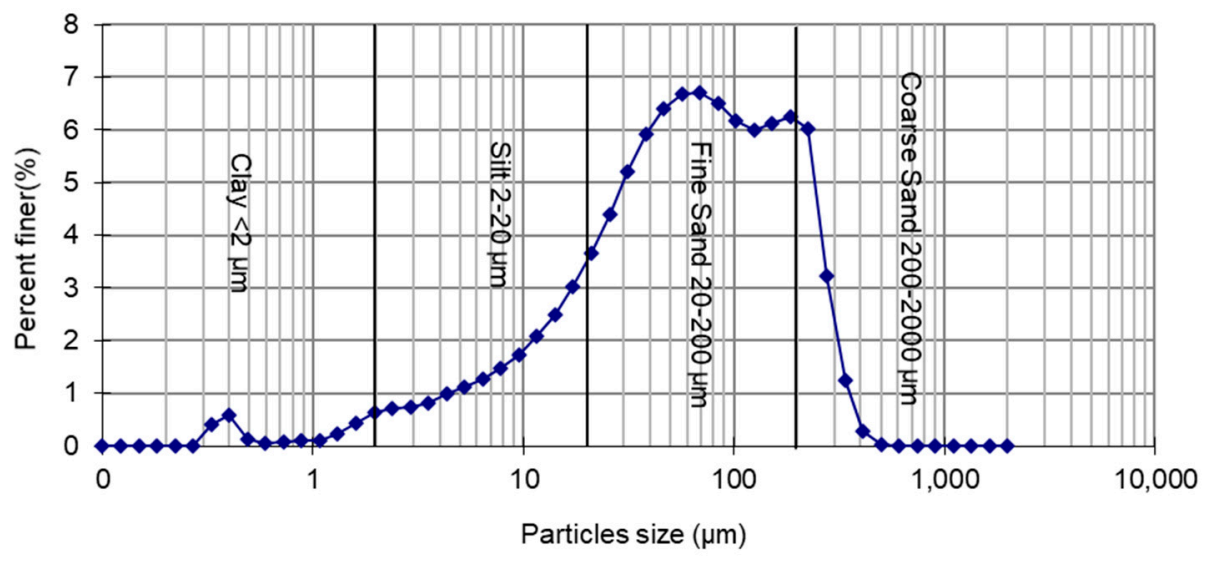

Figure 1. Particle size distribution of the clay soil.

Table 1. Particle size distribution of collected clay soil.

\begin{tabular}{ccccccc}
\hline $\begin{array}{c}\text { Coarse } \\
\text { Sand \% }\end{array}$ & Fine Sand \% & Silt \% & Clay \% & $\mathbf{D}_{\mathbf{1 0}}(\mathbf{m m})$ & $\mathbf{D}_{\mathbf{3 0}}(\mathbf{m m})$ & $\mathbf{D}_{\mathbf{6 0}}(\mathbf{m m})$ \\
\hline 10.8 & 75.5 & 11.6 & 2.1 & 0.007 & 0.0258 & 0.058 \\
\hline
\end{tabular}




\subsection{Manufacturing of Porous Clay Bricks}

Figure 2 presents the schematic diagram of the porous clay brick manufacturing process followed in this study. A conventional brick-making method was applied to manufacture the porous clay bricks. Five different series of bricks with different ratios of soil and RB were prepared. The RB ratios of $0 \%, 7.5 \%, 10 \%, 15 \%$, and $20 \%$ of total weight of mixture were named as B-0, B-7.5, B-10, B-15, and B-20. B-0 brick was used as a controlled sample to evaluate the effect of RB on bricks' properties. The weights of the materials were measured using a digital balance. For laboratory testing, several bricks of dimensions $(100 \mathrm{~mm} \times 20 \mathrm{~mm} \times 20 \mathrm{~mm})$ were prepared for each series. For making a homogeneous mixture for porous brick manufacturing, different ratios of soil and RB were combined and well mixed. In the subsequent step, water was gradually added to the mixture and mixed well to form the dough with the desired plasticity and workability. The dough was then filled in a rectangular wooden mold $(100 \mathrm{~mm} \times 20 \mathrm{~mm} \times 20 \mathrm{~mm})$ to make porous bricks, which were sun-dried for $48-72 \mathrm{~h}$. Finally, the sundried bricks were fired in a muffle furnace in the laboratory at $900^{\circ} \mathrm{C}$ temperature with a gradual increase of $10^{\circ} \mathrm{C} / \mathrm{min}$ for $2 \mathrm{~h}$ duration. Figure 3 shows a sample of the final product of the clay brick.

\subsection{Testing of Porous Clay Bricks}

\subsubsection{Mechanical, Physical, and Hydrological Properties}

The structural (mechanical and physical properties), hydrological (permeability), and water treatability performances of the porous clay bricks were evaluated for their potential application to PCP. Compressive strength, flexural strength, porosity, water adsorption, bulk density, permeability, and filtration of the clay bricks were tested. All the experiments were carried out in triplicate to ensure the reproducibility of the results. The following section presents averages and standard deviations of the tests performed.

The apparent porosity, water adsorption, and bulk density of the bricks were tested according to ASTM Methods [36]. The test was based on the water boiling method where samples were dried at $110^{\circ} \mathrm{C}$ and weight the dry mass using balance. The samples were then placed in distilled water and boiled for $2 \mathrm{~h}$. After boiling and cooling, saturated weight of the samples was determined. Apparent porosity, water adsorption, and bulk density were then calculated using the following equations:

$$
\begin{gathered}
P, \%=\frac{W-D}{V} \times 100 \\
W A, \%=\frac{W-D}{D} \times 100 \\
B\left(\mathrm{gm} / \mathrm{cm}^{3}\right)=\frac{D}{V} \times 100
\end{gathered}
$$

where, $p$ is the porosity of the bricks (\%), WA is the water adsorption (\%), $B$ is the bulk density $\left(\mathrm{g} / \mathrm{cm}^{3}\right), W$ is the saturated weight $(\mathrm{g}), D$ is the dry weight $(\mathrm{g})$, and $V$ is the volume of brick sample $\left(\mathrm{cm}^{3}\right)$. 


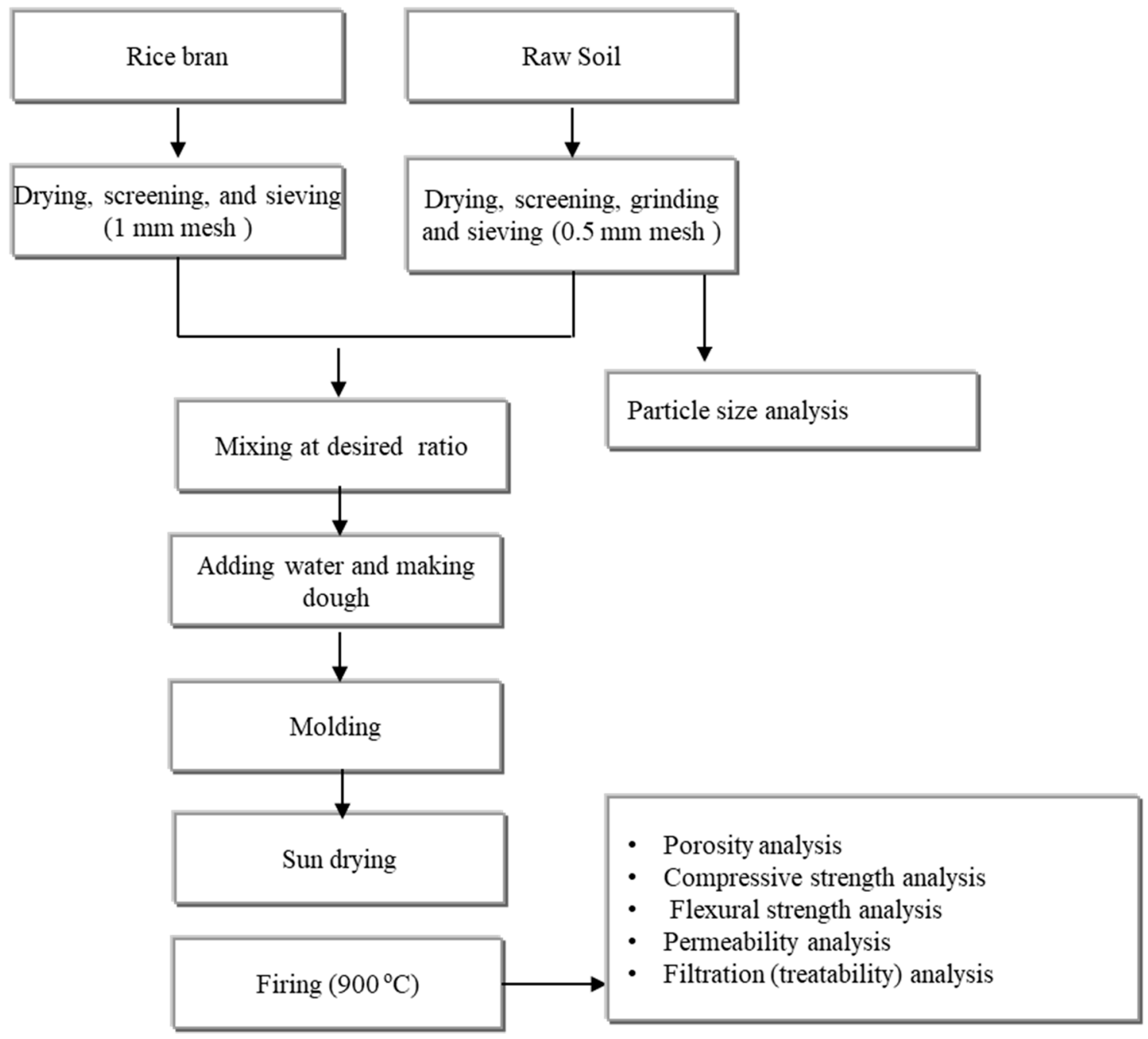

Figure 2. Schematic Diagram of permeable bricks manufacturing process.

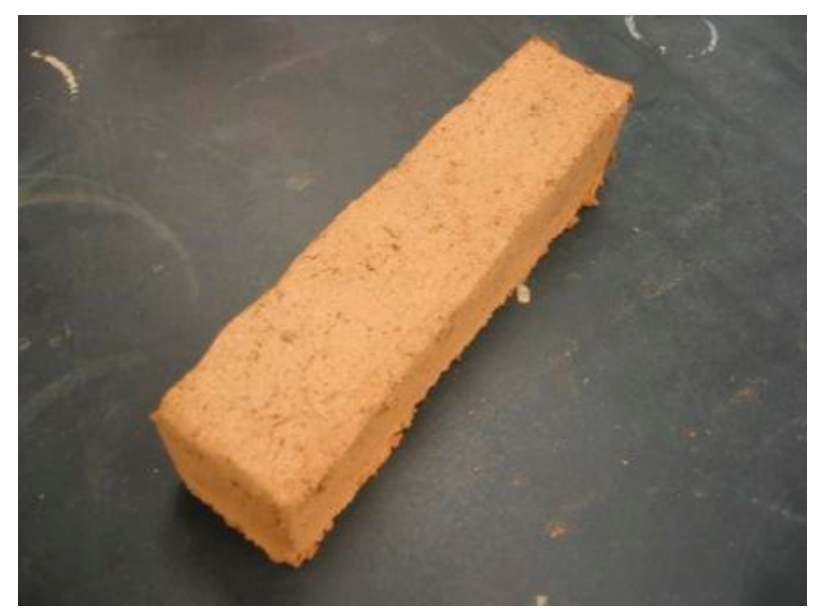

Figure 3. Sample of porous clay brick manufactured for this study (Size: $100 \mathrm{~mm} \times 20 \mathrm{~mm} \times 20 \mathrm{~mm}$ ).

Compressive strength test were carried out to determine the load carrying capacity of the bricks under compression. Compressive strength tests were performed by a universal testing machine (UTM) according to the methods described by ASTM C67-05 [37]. For the compression strength tests, the brick specimens $(100 \mathrm{~mm} \times 20 \mathrm{~mm} \times 20 \mathrm{~mm})$ were secured between the two pressing discs fitted in the machine and pressed until the complete failure 
(breakage) of the brick. The pressure at failure was recorded from the pressure gauge attached to the machine. Compressive strength was calculated using following equation:

$$
F_{C S}=P / A \text {. }
$$

where, $F_{c s}$ is the compressive strength of specimens (MPa), $P$ is the maximum load applied $(N)$ to break specimens, and $A$ is the cross-sectional area of the specimen $\left(\mathrm{mm}^{2}\right)$.

Three-point bending tests were undertaken for determine the flexural strength using UTM according to ASTM E72-15 [38]. For flexural strength test, the bricks specimens $(100 \mathrm{~mm} \times 20 \mathrm{~mm} \times 20 \mathrm{~mm})$ were placed under the UTM machine and force was applied until complete failure. Flexural strength $\sigma$ was calculated using following equation:

$$
\sigma=\frac{3}{2} \frac{P L}{b d^{2}}
$$

where, $\sigma$ is the flexural strength (MPa), $L$ is the length of the specimen (mm), $b$ is the width of the specimen $(\mathrm{mm})$, and $d$ is the thickness of the specimen $(\mathrm{mm})$.

The permeability coefficient of bricks was determined according to the standard falling head permeability test ASTM D2434-68 [39]. The test was carried out with a transparent plastic cylinder having a valve at the bottom. At the beginning, the test specimen $(20 \mathrm{~mm} \times 20 \mathrm{~mm} \times 20 \mathrm{~mm}$ bricks) was fixed at the bottom of the cylinder just above the valve. After placing the specimen, the cylinder was filled with water to a certain height $\left(\mathrm{h}_{1}\right)$ and kept for at least $2 \mathrm{~h}$. to ensure the bricks specimen is saturated with water. The permeability test was then started by opening the valve connected at the bottom of the cylinder and time $(t)$ was measured until water height reached $h_{2}$. The permeability coefficient was then calculated using Equation (6).

$$
k=\frac{a \times l}{A \times t} \ln \left(\frac{\mathrm{h}_{1}}{\mathrm{~h}_{2}}\right) .
$$

here $a$ is the cross section of the cylinder, $l$ is the thickness of the specimen, $h_{1}$ is the initial height of water, and $h_{2}$ is the height of water at time $t$.

\subsubsection{Filtration Experiments}

A filtration test was performed to determine the stormwater treatment efficiency of the porous clay brick manufactured in the present study. Figure 4 shows the schematics of filtration experiments, which consisted of a plastic cylinder (used as filtration tank), two suction pumps, a feed water tank and a final water tank. Natural stormwater was collected, immediately after a rain event, from a stormwater storage pond located at $26.3489^{\circ} \mathrm{N}$ and $43.7668^{\circ} \mathrm{E}$ in Qassim University (QU) Campus, Buraydah (Qassim, Saudi Arabia). The pond with an area of $2500 \mathrm{~m}^{2}$ receives stormwater from the catchment area of approximately $1.4 \mathrm{~km}^{2}$. Triplicate storm water samples were collected from three different locations in pre-washed high-density polyethylene (HDPE) bottles and transported to the laboratory for succeeding analysis. All the samples were stored in refrigerator at $4{ }^{\circ} \mathrm{C}$ without any treatment and analyzed for $\mathrm{pH}$, dissolved oxygen (DO), five days' biochemical oxygen demand $\left(\mathrm{BOD}_{5}\right)$, and chemical oxygen demand (COD) within $48 \mathrm{~h}$ of sampling. For filtration experiments, raw stormwater was fed to the filtration tank inside which a B-20 porous brick was submerged. B-20 brick was selected due to its higher porosity than the remaining samples. Therefore, B-20 brick was used as the reference brick to test the removal efficiency of stormwater contaminants. A vacuum pump was used to suck the water through the bricks at an average surface flow rate of $110 \mathrm{~L} / \mathrm{m}^{2}-\mathrm{h}$. This flow rate was selected to check the filtration performance in the worst-case scenario of an extremely heavy rainfall event. The filtered water (final water) flowed through the effluent tube to the final water tank. Filtration tests were performed for three consecutive days, and filtrated water was collected on a daily basis and analyzed for water quality. 


\subsubsection{Water Quality Testing of Filtered Water}

Physico-chemical analyses of all filtered water samples were performed according to the methods defined by American Public Health Association [40]. Electrical conductivity (EC), $\mathrm{pH}$, and $\mathrm{DO}$ were measured using the Hach $(\mathrm{HACH}$, Loveland, $\mathrm{CO}, \mathrm{USA})$ portable $\mathrm{pH}, \mathrm{EC}$, and DO meter. Turbidity was measured with the help of Hach 2100Q turbidity meter (2100Q, HACH, Loveland, CO, USA). Total dissolved solids (TDS) were measured using Hach HQ411d TDS meter (HACH, Loveland, CO, USA). Alkalinity was measured by titration with sulfuric acid. $\mathrm{BOD}_{5}$ was measured following the standard procedure of 5-day BOD test as prescribed in APHA (APHA, 2005). Total organic matter (TOC) was determined by a TOC analyzer (Shimadzu, Japan). A Hach-DR5000 UV-Vis (ultraviolet-visible) Spectrophotometer was used to measure COD (reactor digestion method), and phosphate phosphorus $\left(\mathrm{PO}_{4}-\mathrm{P}\right)$ (acid per-sulfate digestion method). Total nitrogen (TN) was also measured as per APHA (2005). Nitrate $\left(\mathrm{NO}_{3}-\mathrm{N}\right)$, nitrite $\left(\mathrm{NO}_{2}-\mathrm{N}\right)$ and ammonia $\left(\mathrm{NH}_{3}-\mathrm{N}\right)$ nitrogen were measured, respectively by nitrate electrode method, colorimetric method, and titrimetric method. Heavy metals including iron (Fe), manganese $(\mathrm{Mn})$, lead $(\mathrm{Pb})$, zinc $(\mathrm{Zn})$, nickel $(\mathrm{Ni})$, copper $(\mathrm{Cu})$, cadmium $(\mathrm{Cd})$, selenium $(\mathrm{Se})$, barium $(\mathrm{Ba})$ and chromium $(\mathrm{Cr})$ were measured using an inductive coupled plasma mass spectrometer (PerkinElmer, NexION ${ }^{\mathrm{TM}} 300$ ICP-MS).

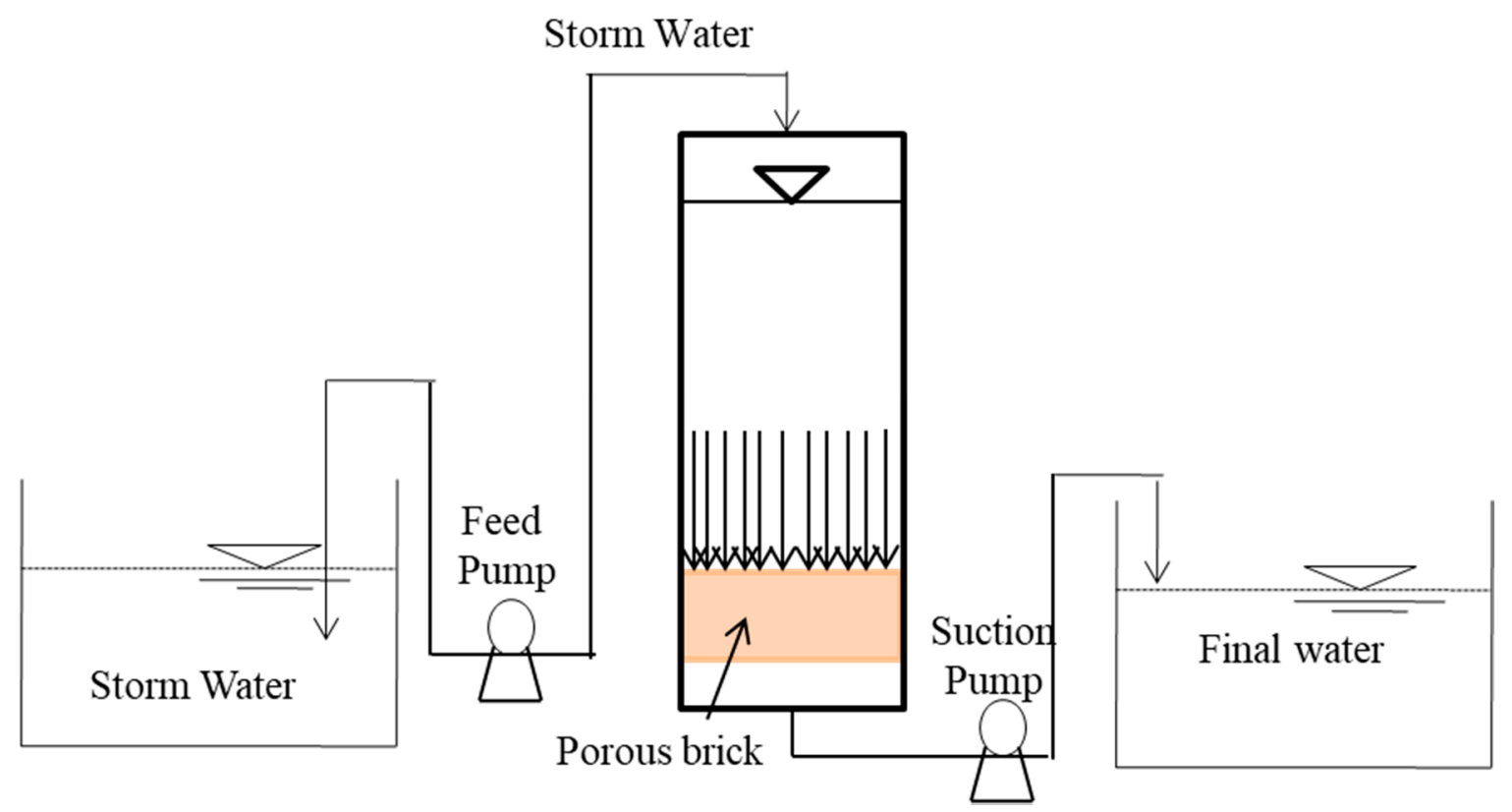

Figure 4. Filtration experiments with porous B-20 brick.

\subsection{Statistical Analysis}

Single factor analysis of variance (ANOVA) was performed to compare all the porous brick samples based on their structural and hydraulic performances, e.g., porosity, water adsorption, and bulk density. Percentage of rise barn was the only factor while the number of observations (triplicate tests) for each level were observed responses and was a random variable for the standard ANOVA. Microsoft Excel performed ANOVA to establish whether the two levels were statistically different from each other or not. The difference was considered significant for $p$-value $<0.05$. 


\section{Results and Discussion}

\subsection{Results}

\subsubsection{Porosity, Water Adsorption, and Bulk Density}

Properties of aperient porosity, water absorption and bulk density can be used as performance indicators to assess the quality of the brick. Table 2 shows the variations of average porosity, water absorption, and bulk density for porous clay bricks as a function of RB\%. Table 2 presents that the average porosity increased significantly $(p<0.05)$ with increasing $\mathrm{RB} \%$. These results indicate that RB played a key role in the clay-RB mixture. Around $10 \%$ porosity was achieved for controlled (B-0) brick samples, whereas it increased to an average of $59 \%$ for B-20 brick. Bulk density of $1.9 \mathrm{~g} / \mathrm{cm}^{3}$ for B-0 brick significantly $(p<0.05)$ decreased to $1.3 \mathrm{~g} / \mathrm{cm}^{3}$ as RB \% increased from $0 \%$ to $20 \%$. For water adsorption, values significantly increased $(p<0.05)$ with increasing $\mathrm{RB} \%$, achieving a minimum $10.5 \%$ for B-0 and a maximum $39.3 \%$ for B-20. These results indicate that the addition of RB in clay mixture increased both porosity and water absorption as well as decreased bulk density, which eventually made the bricks lighter than conventional bricks. Theoretically, during the burning steps of clay brick, biomass (rice bran) particles were burnt out to ash and created pores in the bricks. The number of pores increased with increasing RB ratio, which eventually increased the infiltration capability (permeability) of the bricks and acted as a direct filter for the rainwater runoff.

Table 2. Porosity, water adsorption and bulk density of porous clay bricks as a function of rice bran $(\mathrm{RB}) \%$.

\begin{tabular}{cccccc}
\hline Parameters & B-0 & B-7.5 & B-10 & B-15 & B-20 \\
\hline Porosity $(\%)$ & $10.1 \pm 1.7$ & $21.7 \pm 2.2$ & $29.2 \pm 1.8$ & $39.0 \pm 2.5$ & $59.1 \pm 2.5$ \\
Water adsorption $(\%)$ & $10.5 \pm 1.4$ & $15.2 \pm 0.7$ & $22.3 \pm 4.0$ & $27.8 \pm 2.9$ & $39.3 \pm 3.5$ \\
bulk density $\left(\mathrm{kg} / \mathrm{m}^{3}\right)$ & $1.9 \pm 0.07$ & $1.7 \pm 0.05$ & $1.61 \pm 0.04$ & $1.51 \pm 0.03$ & $1.3 \pm 0.04$ \\
\hline
\end{tabular}

\pm standard deviation of triplicate samples.

\subsubsection{Compressive and Flexural Strength}

The compressive and flexural strengths of the bricks are amongst the key parameters to evaluate their practicality for pavements and building construction applications. Figure 5 illustrates the compressive and flexural strengths for five series of clay bricks. Both the compressive and flexural strengths showed a decreasing pattern with an increase in $\mathrm{RB} \%$. Bricks with $0 \%$ of RB (B-0) achieved $29.7 \pm 4.2 \mathrm{MPa}$ of compressive strength that further significantly $(p<0.05)$ reduced to $18.8 \pm 4.9 \mathrm{MPa}$ for B-10. Relatively low compressive strength of $6.98 \pm 3.7 \mathrm{MPa}$ was achieved with $20 \%$ of RB. While $1.45 \pm 0.49 \mathrm{MPa}$ flexural strength was achieved for B-0 that significantly $(p<0.05)$ reduced to $0.27 \pm 0.14 \mathrm{MPa}$ for $\mathrm{B}-20$. These results indicate that RB in the clay destabilized the inter-particles bond between clay particles. 


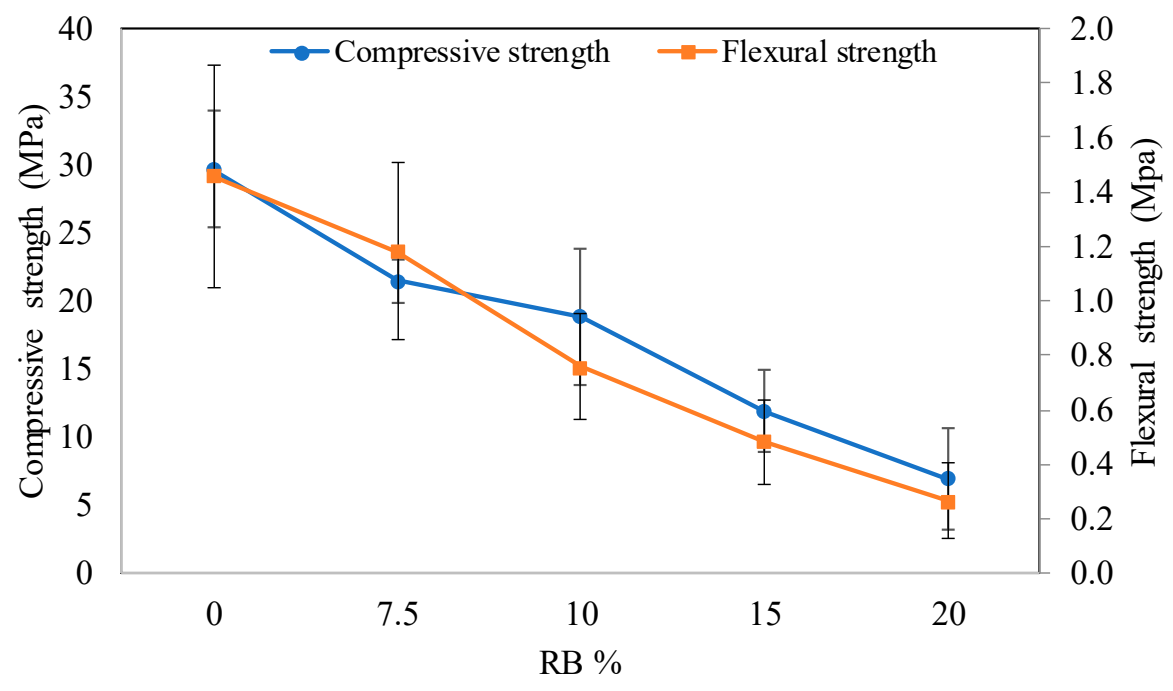

Figure 5. Compressive and flexural strength of permeable clay bricks as a function of RB\%.

The burning process completely decomposes the organic matter present in the RB and generates pores in the bricks' structure, which significantly reduces the strength of bricks [41]. These results are also an outcome of the increased porosity of the bricks as the strength decreased with an increase in RB\% (see Table 2 and Figure 6). Figure 6 demonstrates that the compressive strength of the studied bricks drastically decreased with increasing porosity or bricks. As per the ASTM specifications [42], for pedestrian and light traffic paving bricks (C 902), the minimum compressive strength of individual bricks has been set to $\geq 17.2 \mathrm{MPa}$ (2500 Psi) both for SW (severe weather) and moderate weather (MW) conditions.

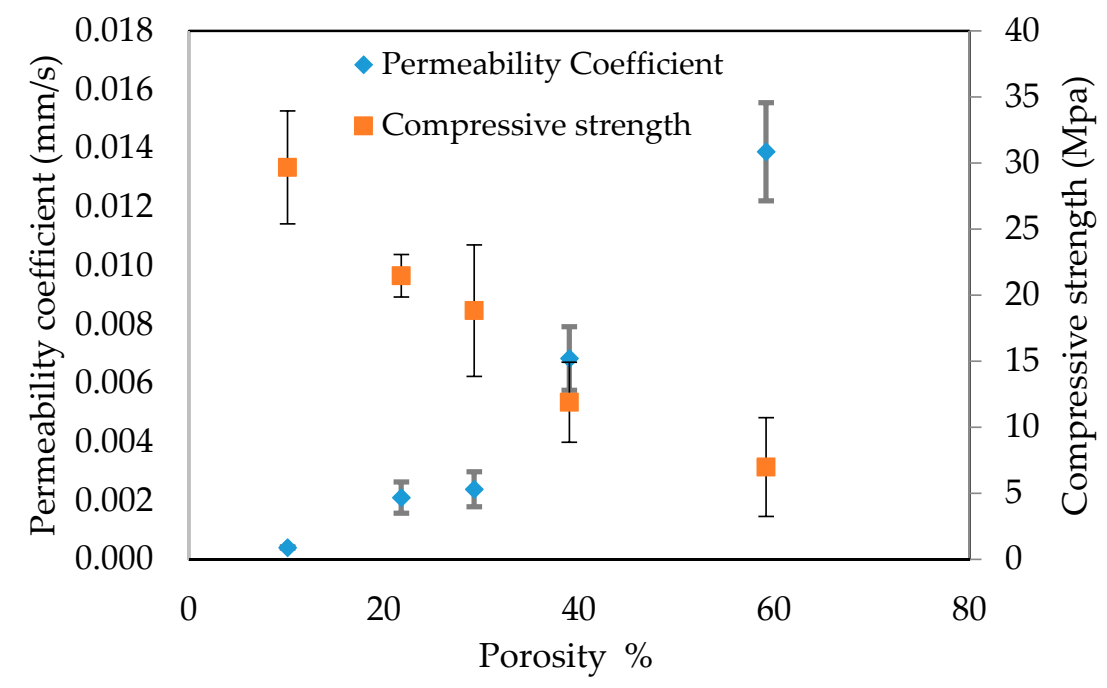

Figure 6. Permeability coefficient and compressive strength of permeable clay bricks as a function of bricks' porosity.

\subsubsection{Permeability Coefficient}

Figure 7 shows the coefficient of permeability for the studied bricks as a function of $\mathrm{RB} \%$. As expected, the permeability increased as the percentage of rice barn increase. Eventually, the permeability decreased with the porosity as presented in Figure 6. These results are in close agreement with a recent study, which reported that the permeability coefficient considerably reduced with an increase in total porosity of pervious concrete [43]. 
Permeability coefficient was found to be $2.1 \times 10^{-3} \mathrm{~mm} / \mathrm{s}$ for B-7.5 and $2.38 \times 10^{-3} \mathrm{~mm} / \mathrm{s}$ for B-10. These values of permeability coefficient are within the range of typical values for permeable pavements. According to the literature, media having a coefficient of permeability greater than $10^{-3} \mathrm{~mm} / \mathrm{s}$ is pervious and media within $10^{-3}$ to $10^{-5} \mathrm{~mm} / \mathrm{s}$ is semi-pervious [44]. Such values of permeability coefficient suggested that B-7.5 and B-10 bricks can be applied to the design and construction of permeable pavements.

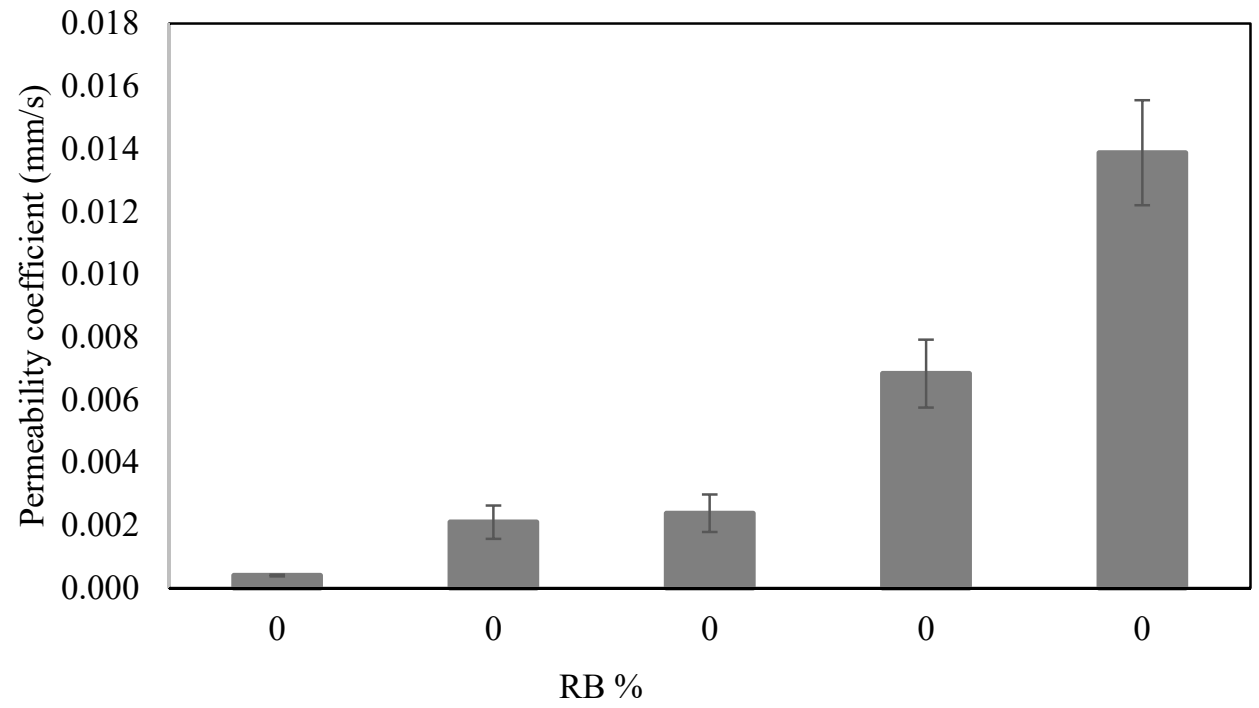

Figure 7. Coefficient of permeability of the clay bricks as a function of RB\%.

\subsection{Stormwater Treatment Efficiency}

Finally, the brick with higher permeability (i.e., B-20) was used to perform filtration experiments to evaluate its performance for the removal of contaminants from stormwater. Table 3 shows the concentrations of contaminants in both the raw stormwater and filtrated samples. No changes were found for $\mathrm{pH}, \mathrm{DO}$, and TDS values in both the raw and filtered samples. Nevertheless, TDS in none of the stormwater samples exceeded the maximum limit of the World Health Organization (WHO) standard for wastewater reuse [45]. $\mathrm{pH}$ values remained between 7 and 8 while $\mathrm{DO}$ concentrations remained around $7.8 \mathrm{mg} / \mathrm{L}$. Alkalinity slightly increased from $28 \mathrm{mg} / \mathrm{L}$ to $41 \mathrm{mg} / \mathrm{L}$ after filtration. Electrical conductivity (EC) remained almost unchanged with $614 \mu \mathrm{s} / \mathrm{cm}$ at the influent and $612 \mu \mathrm{s} / \mathrm{cm}$ at the effluent. Efficient removals for TSS and turbidity were achieved while stormwater filtered through the porous brick. For turbidity, 98.5\% removal was achieved with an average effluent value of 0.39 NTU. In the same way, more than $97 \%$ removal of TSS was achieved with the average TSS value of $5.0 \mathrm{mg} / \mathrm{L}$ at the effluent.

Efficiency of organic removal exposed the average $\mathrm{BOD}_{5}$ removal of $76.8 \%$ with the effluent concentration of $5 \mathrm{mg} / \mathrm{L}$. Results demonstrate that the particulate part of the organics is removed by the physical straining of the porous clay bricks surface whereas the dissolved organic component was expected to be removed via adsorption on to the surface of clay bricks. These results of the present study are in agreement with a pervious study that reported some sorption capabilities of natural clay for the removal of organics from wastewater [46]. The performance of the brick was found to be relatively poor for the removal of nutrients, i.e., $3.4 \%, 42.8 \%, 12.5 \%, 23.9$ and $23.4 \%$, removals for $\mathrm{TN}, \mathrm{NH}_{3}-\mathrm{N}$, $\mathrm{NO}_{2}-\mathrm{N}$, and $\mathrm{NO}_{3}-\mathrm{N}$, and $\mathrm{PO}_{4}-\mathrm{P}$. 
Table 3. Stormwater treatment efficiency of permeable clay brick and comparison with other low-impact development (LID) technologies and reuse standard.

\begin{tabular}{|c|c|c|c|c|c|c|c|c|}
\hline \multirow[b]{2}{*}{ Parameters } & \multicolumn{3}{|c|}{$\begin{array}{l}\text { Contaminants Removal by } \\
\text { Permeable Bricks (This Study) }\end{array}$} & \multicolumn{4}{|c|}{$\begin{array}{c}\text { Contaminants Removal \% by Other LID } \\
\text { Technologies }\end{array}$} & \multirow{2}{*}{$\begin{array}{c}\text { Wastewater } \\
\text { Reuse } \\
\text { Standard }^{\mathrm{c}}\end{array}$} \\
\hline & $\begin{array}{c}\text { Raw } \\
\text { Stormwa- } \\
\text { ter }\end{array}$ & $\begin{array}{c}\text { After } \\
\text { Filtration } \\
\quad *\end{array}$ & $\begin{array}{l}\text { Removal } \\
(\%)\end{array}$ & 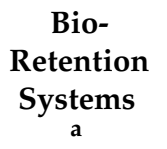 & $\begin{array}{l}\text { Permeable } \\
\text { Pave- } \\
\text { ments } \\
\text { a }\end{array}$ & $\begin{array}{c}\text { Grass } \\
\text { Swales }^{\text {a }}\end{array}$ & $\begin{array}{l}\text { Sand } \\
\text { Filter }^{b}\end{array}$ & \\
\hline $\mathrm{pH}$ & 7.7 & 7.6 & - & & & & & $6.0-9.0$ \\
\hline $\begin{array}{l}\text { Suspended Solids } \\
\text { (mg/L) }\end{array}$ & 345 & 5.0 & 98.5 & $47-99$ & $58-94$ & $46-97$ & $32-93.5$ & - \\
\hline Alkalinity (mg/L) & 28.0 & 41.3 & -47.3 & - & - & - & & - \\
\hline $\mathrm{EC}(\mu \mathrm{s} / \mathrm{cm})$ & 614 & 612 & 0.33 & - & - & - & -0.92 & - \\
\hline $\mathrm{DO}(\mathrm{mg} / \mathrm{L})$ & 7.9 & 7.8 & & - & - & - & - & - \\
\hline Turbidity (NTU) & 13.8 & 0.4 & 97.2 & - & - & - & - & 5 \\
\hline $\operatorname{TDS}(\mathrm{mg} / \mathrm{L})$ & 423 & 413 & 2.0 & - & - & - & - & 2500 \\
\hline $\mathrm{BOD}_{5}(\mathrm{mg} / \mathrm{L})$ & 21.4 & 5.0 & 76.7 & - & - & - & - & - \\
\hline TOC (mg/L) & 3.7 & 3.85 & -5.3 & - & - & $23-64$ & - & - \\
\hline $\mathrm{TN}(\mathrm{mg} / \mathrm{L})$ & 12.0 & 11.6 & 3.4 & 32-99 & $>75$ & $14-61$ & $-34-74$ & - \\
\hline NH3-N (mg/L) & 0.68 & 0.4 & 42.8 & - & - & - & - & - \\
\hline $\mathrm{NO} 2-\mathrm{N}(\mathrm{mg} / \mathrm{L})$ & 0.05 & 0.04 & 12.5 & - & - & - & - & - \\
\hline $\mathrm{NO}_{3}-\mathrm{N}(\mathrm{mg} / \mathrm{L})$ & 4.90 & 3.7 & 23.9 & $1-83$ & & $0-45$ & $0-70$ & - \\
\hline PO4-P (mg/L) & 0.08 & 0.06 & 23.4 & - & - & - & $0-66$ & - \\
\hline $\mathrm{Fe}(\mathrm{mg} / \mathrm{L})$ & 0.00 & 0.00 & 0.0 & - & - & - & - & 5.00 \\
\hline $\operatorname{Mn}(\mathrm{mg} / \mathrm{L})$ & 0.04 & 0.02 & 55.7 & - & - & - & - & 0.20 \\
\hline $\mathrm{B}(\mu \mathrm{g} / \mathrm{L})$ & 35.5 & 65.9 & -84.3 & - & - & - & - & - \\
\hline $\mathrm{Ba}(\mu \mathrm{g} / \mathrm{L})$ & 19.41 & 22.4 & -15.2 & - & - & - & - & - \\
\hline $\mathrm{Cd}(\mu \mathrm{g} / \mathrm{L})$ & ND & ND & - & - & - & $12-98$ & - & - \\
\hline $\mathrm{Cr}(\mu \mathrm{g} / \mathrm{L})$ & 17.9 & 25.7 & -43.4 & & & & & 100 \\
\hline $\mathrm{Cu}(\mu \mathrm{g} / \mathrm{L})$ & 30.3 & 14.7 & 51.6 & $43-97$ & $20-99$ & $14-67$ & $-15-68$ & 200 \\
\hline $\mathrm{Ni}(\mu \mathrm{g} / \mathrm{L})$ & ND & ND & - & & & & & 200 \\
\hline $\mathrm{Pb}(\mu \mathrm{g} / \mathrm{L})$ & ND & ND & - & $31-98$ & $75-99$ & $18-94$ & $-24-98$ & 5000 \\
\hline Se $(\mu \mathrm{g} / \mathrm{L})$ & ND & ND & - & & & & & 20 \\
\hline $\mathrm{Zn}(\mu \mathrm{g} / \mathrm{L})$ & 48.9 & 13.6 & 72.1 & $62-97$ & 73-99 & $47-81$ & 0-93 & 2000 \\
\hline
\end{tabular}

$\mathrm{ND}=$ Not detected. ${ }^{*}$ The average of triplicate samples. ${ }^{\mathrm{a}}$ Ahiablame et al., 2012 [47]. ${ }^{\mathrm{b}}$ Zarezadeh et al., 2018 [48]. ${ }^{\mathrm{c}} \mathrm{WHO}, 2006$ [45].

Removal of some heavy metals including $\mathrm{Mn}, \mathrm{Cu}$, and $\mathrm{Zn}$ from stormwater was achieved whereas $\mathrm{Ba}$ and $\mathrm{Cr}$ were not removed during filtration. The removal efficiency was achieved: $55.2 \%$ for $\mathrm{Mn}, 51.5 \%$ for $\mathrm{Cu}$, and $72.2 \%$ for $\mathrm{Zn}$. Some common heavy metals in stormwater were not detected in any of the samples collected in the present study, such as $\mathrm{Fe}, \mathrm{Cd}, \mathrm{Ni}, \mathrm{Pb}$, and $\mathrm{Se}$. This might be due to the specific characteristics of the catchment area of selected pond.

Table 3 presents a comparison between the characteristics of filtered water, and the wastewater reuse guideline standards recommended by World Health Organization [45]. The WHO recommends the values for recycling water for restricted and unrestricted irrigation, fire protection, and toilet flushing. Water qualities of the filtered samples were found to be suitable for wastewater reuse applications. Nevertheless, the microbiological quality must satisfy the guidelines as that was not considered in the present study.

\subsection{Discussion}

Among all the bricks tested in this study, B-7.5 and B-10 fall in the grade SW and MW for pedestrian and light traffic (cycling) paving. Although, B-20 showed a significantly higher permeability coefficient of $1.3 \times 10^{-2} \mathrm{~mm} / \mathrm{s}$ which lies within the range of high permeable media, the compressive strength of B-20 is lower than the ASTM standard for permeable pavement (see Figure 5). Thus, it is recommended to keep the RB $\leq 10 \%$ for porous brick manufacturing to fulfill the minimum compressive strength set by ASTM for 
porous pavements. The overall results of the filtration test revealed that clay bricks produced in this research are capable of removing several important contaminants (organic, inorganic, and heavy metals) from urban runoff. Thus, the clay bricks have significant potential to apply in the construction of preamble pavements in arid and semi-arid conditions.

Figure 8 demonstrates a few potential applications of the clay brick in an urban setting. Based on structural, hydraulic, and treatability performances, the low-cost permeable clay brick developed in the present study can be used as an effective LID technology for the following cases. For underdeveloped countries (e.g., Africa) in arid regions with no stormwater drainage infrastructure, the use of clay bricks in semi-urban and urban areas (also see Figure 8) can recharge groundwater and minimize the risk of flooding by reducing the load on the sanitary drainage system. For developing countries (e.g., South Asia) with partially combined storm drainage infrastructure, the porous pavement can reduce the load on sanitary sewers (with some stormwater allowance) and minimize the flooding risk in the case of frequent and high-intensity rainfalls in semi-arid to semi-tropical regions.
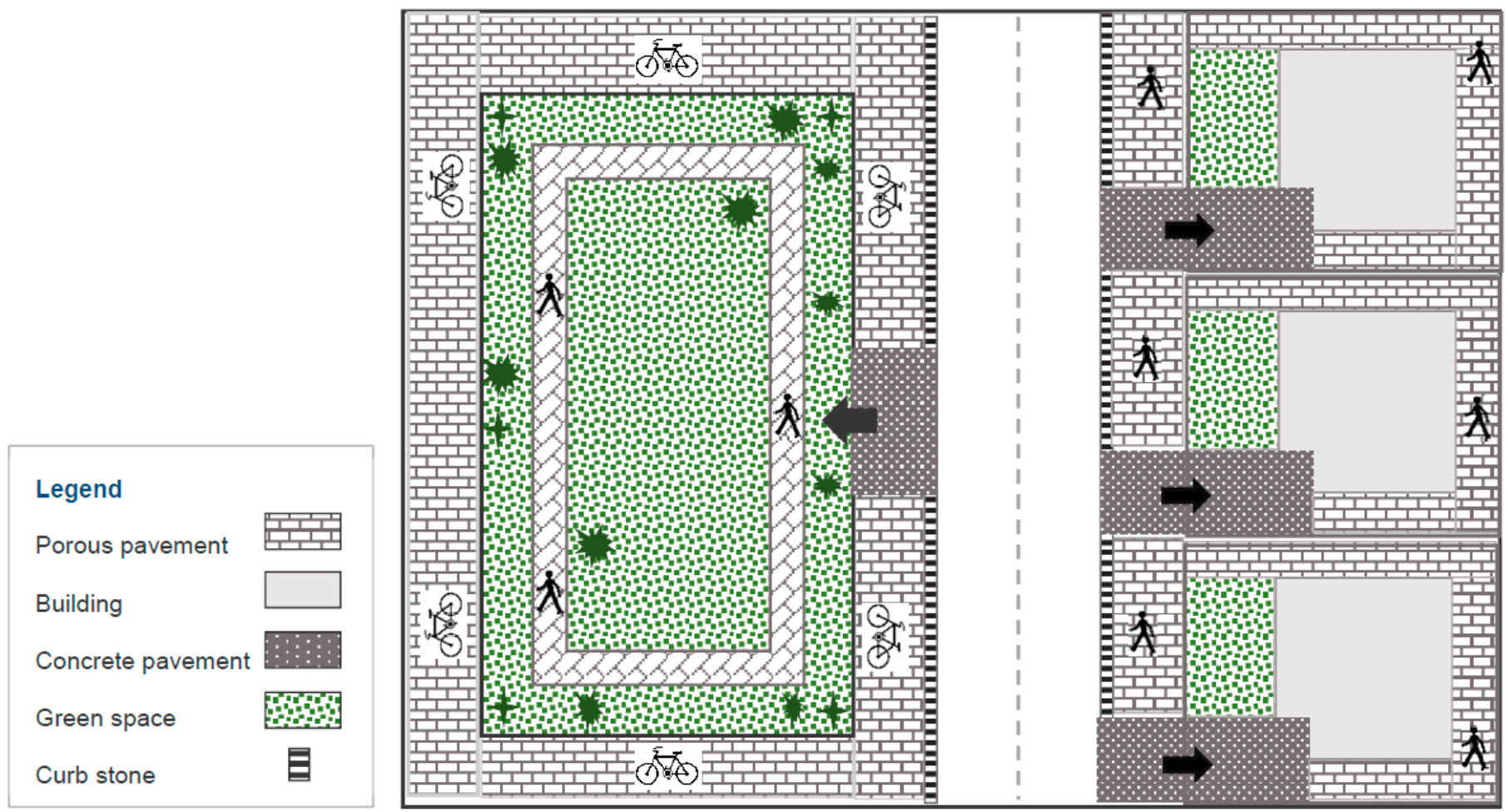

Figure 8. Potential applications of porous pavements with clay bricks in an urban setting.

In the recent past, the frequency of flash floods has been increasing in the Gulf countries, primarily due to global climate change. Most of the urban areas in this region, with semi-arid to arid climatic conditions, have limited capacity storm drainage infrastructure (e.g., 2 to 5-year return period). In 2009, the City of Jeddah in Saudi Arabia experienced devastating losses of property, vehicles, and life. The study area (Buraydah, Qassim) faced a similar situation in terms of economic loss in November 2015 [6]. The rest of the country, and even the Gulf Region, are not dissimilar. For countries with emerging economies in arid regions (e.g., the Gulf) with separate or no storm drainage infrastructure, porous pavements constructed with clay bricks will improve the infiltration of valuable stormwater. In case of very low capacity (e.g., 2-year return period) storm drainage infrastructure, the pavements will help during high floods experienced in the recent past due to climate change. The findings of the present research will help utility managers to plan more cost-effective and sustainable LID technologies in the future. 


\section{Conclusions and Recommendations}

Preamble bricks made of clay soil and rice bran show high potential to be used as pedestrian and light traffic pavements. The ratio of rice bran showed a significant effect on bricks' properties. The bricks made of a relatively lower percentage of rice bran (i.e., RB $\leq 10 \%$ ) achieved the ASTM standard for pedestrian and light traffic paving bricks. Porosity and water adsorption reached $29.2 \%$ and $22.3 \%$, respectively, for the bricks made of $10 \%$ rice bran. Compressive strength and permeability coefficient decreased with increasing percentage of RB in the soil. Compressive strength reached $18.8 \mathrm{MPa}$ with $10 \%$ RB which meets the ASTM standards for pedestrian and light traffic paving bricks. The permeability coefficient for $10 \%$ rice bran bricks was $2.1 \times 10^{-3} \mathrm{~mm} / \mathrm{s}$ which is within the range of permeable pavement media. Filtration test results showed efficient contaminants removal by the studied permeable bricks. Significant removal of turbidity, $\mathrm{SS}, \mathrm{BOD}_{5}$, heavy metals $(\mathrm{Mn}, \mathrm{Cu}, \mathrm{Zn}$ ) from stormwater runoff was observed. The porous bricks prepared in this study would have the potential to be used in urban area (parks, lawn, front yard, footpath etc.) to reduce the urban runoff and their pollutants.

An experimental study with actual brick size is recommended to ensure the sustainability of the studied brick for practical implementation. A future study to improve the compressive strength and permeability of studied bricks by carefully selecting the grain size of RB or combining with some other additives materials such as cement is also recommended. Detailed analysis of pore size distribution, Young modulus and Poisson's ratio of the bricks are also recommended for a future study.

Author Contributions: Conceptualization, M.A. and M.S.; Data curation, F.A., M.S. and H.H.; Formal analysis, F.A.; Funding acquisition, M.S.; Investigation, F.A., M.A. and M.S.; Methodology, F.A., M.A. and M.S.; Project administration, M.A. and M.S.; Resources, M.R.; Supervision, M.S.; Visualization, H.H.; Writing—original draft, M.S. and H.H.; Writing—review and editing, M.R., A.A., S.E., E.A.B. and Y.E.-G. All the authors shared their expert opinion and indigenous knowledge for data curation, visualization. All authors have read and agreed to the published version of the manuscript.

Funding: The authors gratefully acknowledge Qassim University, represented by Deanship of Scientific Research, on the financial support for this research under the number (10184-qec-2020-1-3-I) during the academic year 1441 AH/2020 AD.

Institutional Review Board Statement: Not applicable.

Informed Consent Statement: Not applicable.

Data Availability Statement: Not applicable.

Conflicts of Interest: The authors declare no conflict of interest.

\section{References}

1. Alotaibi, K.; Ghumman, A.R.; Haider, H.; Ghazaw, Y.M. Shafiquzzaman Future Predictions of Rainfall and Temperature Using GCM and ANN for Arid Regions: A Case Study for the Qassim Region, Saudi Arabia. Water 2018, 10, 1260. [CrossRef]

2. Ghumman, A.R.; Ghazaw, Y.M.; Alodah, A.; Shafiquzzaman, M.; Haider, H. Identification of Parameters of Evaporation Equations Using an Optimization Technique Based on Pan Evaporation. Water 2020, 12, 228. [CrossRef]

3. Brabec, E.; Schulte, S.; Richards, P.L. Impervious surfaces and water quality: A review of current literature and its implications for watershed planning. J. Plan. Lit. 2002, 16, 499-514. [CrossRef]

4. Brattebo, B.O.; Booth, D.B. Long-term stormwater quantity and quality performance of permeable pavement systems. Water Res. 2003, 37, 4369-4376. [CrossRef]

5. Newman, A.P.; Aitken, D.; Antizar-Ladislao, B. Stormwater quality performance of a macro-pervious pavement car park installation equipped with channel drain based oil and silt retention devices. Water Res. 2013, 47, 7327-7336. [CrossRef] [PubMed]

6. Haider, H.; Ghumman, A.R.; Al-Salamah, I.S.; Ghazaw, Y.; Abdel-Maguid, R.H. Sustainability evaluation of rainwater harvesting based flood risk management strategies: A multilevel decision-making framework for arid environments. Arab. J. Sci. Eng. 2019, 10, 8465-8488. [CrossRef]

7. Mugume, S.N.; Gomez, D.E.; Fu, G.; Farmani, R.; Butler, D. A global analysis approach for investigating structural resilience in urban drainage systems. Water Res. 2015, 81, 15-26. [CrossRef]

8. Low Impact development Center. Available online: http://www.lid-stormwater.net/contact.htm (accessed on 24 November 2020). 
9. USEPA. Green Infrastructure in the Semi-Arid West, Low-Impact Development and Green Infrastructure in the Semi-Arid West. Available online: https://www.epa.gov/green-infrastructure/green-infrastructure-semi-arid-west\#6 (accessed on 20 November 2020).

10. Antunes, L.N.; Ghisi, E.; Thives, L.P. Permeable pavements life cycle assessment: A literature review. Water 2018, 10, 1575. [CrossRef]

11. Scholz, M.; Grabowiecki, P. Review of permeable pavement systems. Build Environ. 2007, 42, 3830-3836. [CrossRef]

12. Sansalone, J.; Kuang, X.; Ying, G.; Ranieri, V. Filtration and clogging of permeable pavement loaded by urban drainage. Water Res. 2012, 46, 6763-6774. [CrossRef]

13. Mullaney, J.; Lucke, T. Practical Review of Pervious Pavement Designs. CLEAN Soil Air Water 2013, 42, 111-124. [CrossRef]

14. Sounthararajah, D.P.; Loganathan, P.; Kandasamy, J.; Vigneswaran, S. Removing heavy metals using permeable pavement system with a titanate nano-fibrous adsorbent column as a post treatment. Chemosphere 2017, 168, 467-473. [CrossRef] [PubMed]

15. Vadas, T.M.; Smith, M.; Luan, H.W. Leaching and retention of dissolved metals in particulate loaded pervious concrete columns. J. Environ. Manag. 2017, 190, 1-8. [CrossRef] [PubMed]

16. Zhang, K.; Yong, F.; McCarthy, D.T.; Deletic, A. Predicting long term removal of heavy metals from porous pavements for stormwater treatment. Water Res. 2018, 142, 236-245. [CrossRef] [PubMed]

17. Pagotto, C.; Legret, M.; Le Cloirec, P. Comparison of the hydraulic behaviour and the quality of highway runoff water according to the type of pavement. Water Res. 2000, 34, 4446-4454. [CrossRef]

18. Fwa, T.F.; Lim, E.; Tan, K.H. Comparison of permeability and clogging characteristics of porous asphalt and pervious concrete pavement materials. Transport. Res. Rec. 2015, 2511, 72-80. [CrossRef]

19. Chandrappa, A.K.; Biligiri, K.P. Pervious concrete as a sustainable pavement material-research findings and future prospects: A state-of-the-art review. Constr. Build. Mater. 2016, 111, 262-274. [CrossRef]

20. Associação Brasileira de Normas Técnicas (ABNT). NBR 16416/2015: Pavimentos Permeáveis de Concreto-Requisitos e Procedimentos (NBR 16416/2015: Pervious Concrete Pavement_Requirements and Procedures); Associação Brasileira de Normas Técnicas: São Paulo, Brazil, 2015.

21. Marcaida, A.K.; Nguyen, T.H.; Ahn, J. Investigation of particle-related clogging of sustainable concrete pavements. Sustainability 2018, 10, 4845. [CrossRef]

22. Elizondo-Martinez, E.J.; Tataranni, P.; Rodriguez-Hernandez, J.; Castro-Fresno, D. Physical and Mechanical Characterization of Sustainable and Innovative Porous Concrete for Urban Pavements Containing Metakaolin. Sustainability 2020, 12, 4243. [CrossRef]

23. Sprouse, C.E., III; Hoover, C.; Obritsch, O.; Thomazin, H. Advancing Pervious Pavements through Nomenclature, Standards, and Holistic Green Design. Sustainability 2020, 12, 7422. [CrossRef]

24. Huang, Y.; Bird, R.; Heidrich, O. Development of a life cycle assessment tool for construction and maintenance of asphalt pavements. J. Clean. Prod. 2009, 17, 283-296. [CrossRef]

25. Wang, Y.; Li, H.; Ghadimi, B.; Abdelhady, A.; Harvey, J. Initial evaluation methodology and case studies for life cycle impact of permeability of permeable pavements. Int. J. Transp. Sci. Technol. 2018, 7, 169-178. [CrossRef]

26. Spatari, S.; Yu, Z.; Montalto, F.A. Life cycle implications of urban green infrastructure. Environ. Pollut. 2011, 159, 2174-2179. [CrossRef] [PubMed]

27. Li, Y.; Huang, Y.; Quanliang, Y.; Zhang, W.; Meng, F.; Zhang, S. Multi-objective optimization integrated with life cycle assessment for rainwater harvesting systems. J. Hydrol. 2018, 558, 659-666. [CrossRef]

28. Biofilico, Organic Building Materials and Their Benefits. Available online: https://biofilico.com/news/2019/12/19/organicbuilding-materials-and-their-benefits (accessed on 15 November 2020).

29. Dondi, M.; Guarini, G.; Raimondo, M.; Zanelli, C.; Fabbriche, D.D.; Agostini, A. Recycling the insoluble residue from titania slag dissolution (tionite) in clay bricks. Ceram. Int. 2010, 36, 2461-2467. [CrossRef]

30. Eliche-Quesada, D.; Corpas-Iglesias, F.A.; Pérez-Villarejo, L.; Iglesias-Godino, F.J. Recycling of sawdust, spent earth from oil filtration, compost and marble residues for brick manufacturing. Constr. Build. Mater. 2012, 34, 275-284. [CrossRef]

31. Faria, K.C.P.; Gurgel, R.F.; Holanda, J.N.F. Recycling of sugarcane bagasse ash waste in the production of clay bricks. J. Environ. Manage. 2012, 101, 7-12. [CrossRef]

32. Bories, C.; Borredon, M.E.; Vedrenne, E.; Vilarem, G. Development of eco-friendly porous fired clay bricks using pore-forming agents: A review. J. Environ. Manag. 2014, 143, 186-196. [CrossRef]

33. Bories, C.; Aouba, L.; Vedrenne, E.; Vilarem, G. Fired clay bricks using agricultural biomass wastes: Study and characterization. Constr. Build. Mater. 2015, 91, 158-163. [CrossRef]

34. Brick Industry Association (BIA). Permeable Clay Brick Pavements; TECHNICAL NOTES on Brick Construction; Brick Industry Association: Reston, VA, USA, 2012.

35. Saleem, M.A.; Kazmi, S.M.S.; Abbas, S. Clay bricks prepared with sugarcane bagasse and rice husk ash-A sustainable solution. MATEC Web Conf. 2017, 120, 03001. [CrossRef]

36. American Society for Testing and Materials (ASTM). Standard Test Methods for Apparent Porosity, Water Absorption, Apparent Specific Gravity, and Bulk Density of Burned Refractory Brick and Shapes by Boiling Water; ASTM International: West Conshohocken, PA, USA, 2000.

37. American Society for Testing and Materials (ASTM). Standard Test Methods for Sampling and Testing Brick and Structural Clay Tile; ASTM International: West Conshohocken, PA, USA, 2005. 
38. American Society for Testing and Materials (ASTM). Standard Test Methods of Conducting Strength Tests of Panels for Building Construction; ASTM International: West Conshohocken, PA, USA, 2015.

39. American Society for Testing and Materials (ASTM). Standard Test Method for Permeability of Granular Soils (Constant Head); ASTM International: West Conshohocken, PA, USA, 2006.

40. American Public Health Association (APHA). Standard Methods for the Examination of Water and Wastewater, 21st ed.; American Public Health Association: Washington, DC, USA, 2005.

41. Khoo, Y.C.; Johari, I.; Ahmad, Z.A. Influence of Rice Husk Ash on the Engineering Properties of Fired-Clay Brick. Advanced Mater. Res. 2013, 795, 14-18. [CrossRef]

42. ASTM. Standard Specification for Pedestrian and Light Traffic Paving Brick; ASTM International: West Conshohocken, PA, USA, 2015.

43. Ziccarelli, M.; Valore, C. Hydraulic conductivity and strength of pervious concrete for deep trench drains. Geomech. Energy Environ. 2019, 18, 41-55. [CrossRef]

44. Mayne, P.W.; Christopher, B.R.; DeJong, J. Manual on Subsurface Investigations National Highway Institute; Publication No. FHWA NHI-01-031; Federal Highway Administration: Washington, DC, USA, 2001; p. 305.

45. World Health Organization (WHO). Guidelines for the Safe Use of Wastewater, Excreta and Greywater; Excreta and Greywater Use in Agriculture; WHO: Geneva, Switzerland, 2006; Volume 4.

46. Ogunmodede, O.T.; Adebayo, O.L.; Ojo, A.A. Enhancing adsorption capacity of clay and application in dye removal from wastewater. Int. Lett. Chem. Physi. Astron. 2014, 39, 35-51. [CrossRef]

47. Ahiablame, L.M.; Engel, B.A.; Chaubey, I. Effectiveness of low impact development practices: Literature review and suggestions for future research. Water Air Soil Pollut. 2012, 223, 4253-4273. [CrossRef]

48. Zarezadeh, V.; Lung, T.; Dorman, T.; Shipley, H.T.; Giacomoni, M. Assessing the performance of sand filter basins in treating urban stormwater runoff. Environ. Monit. Assess. 2018, 190, 697. [CrossRef] [PubMed] 